www. revistadyo.com

\title{
Barriers and drivers of multi-channel e-commerce: A cross-country examination
}

\author{
Emiliano Acquila-Natale, Santiago Iglesias-Pradas, Julián Chaparro-Peláez
}

Recibido: 15 de Octubre de 2018 / Aceptado: 3 de Enero de 2019

\begin{abstract}
This study addresses the lack of integrative and cohesive frameworks to study the variables influencing the development of multi-channel e-commerce. This exploratory research proposes a theory-grounded, comprehensive and systematic model for the study of the development of multi-channel e-commerce, and further refines the model based on a qualitative study. The study performs a cross-country examination to control for the effect of country-specific characteristics and uses data from interviews to managers of ten Spanish and Argentinian companies from different sectors. The results of the analysis identify the main barriers and drivers of multi-channel e-commerce development, which are discussed in detail. Finally, the study highlights the main contributions from the research and details the implications for theory and practice.
\end{abstract}

\section{Keywords}

e-commerce, multi-channel, Spain, Argentina, qualitative analysis, cross-country.

\section{Introduction}

New sales channels and formats, information and communication technologies and changes in lifestyle have transformed consumer shopping behaviors (Frasquet, Mollá, \& Ruiz, 2015; Schröder \& Zaharia, 2008). Since the mid-90s, with the emergence of Internet retailing, companies have changed the way they commercialize and sell their products (Ranganathan \& Ganapathy, 2002) from single-channel -physical or remote- operation to multi-channel models, where companies market their products in one or more channels.

The advent of electronic commerce (e-commerce) has been a turning point for business activities; the traditional paradigm in which consumers visited the physical store to choose and complete their purchases has shifted with the adoption of information technologies to support alternative shopping channels and processes. Thus, reaching consumers in the virtual space with the same quality and personalized

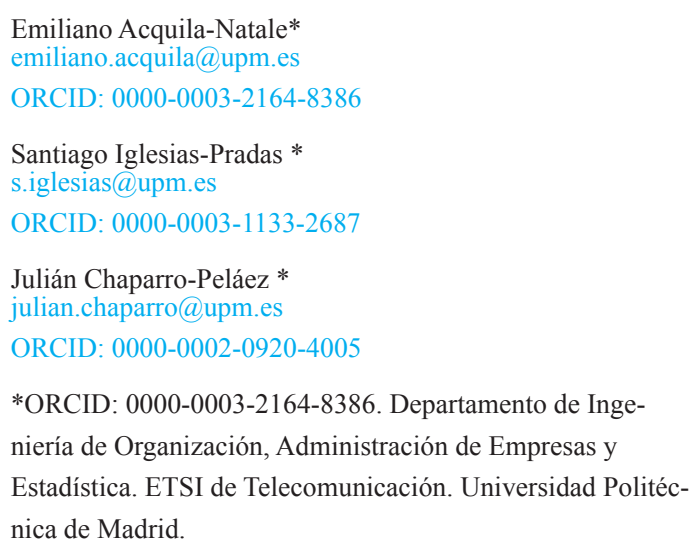

service as in the physical world is now one of the main challenges faced by companies.

The paradigm shift forces companies to rethink their marketing and sales strategies but, despite extensive research on e-commerce, multi-channel electronic commerce (MCEC) has only received limited attention from scholars. This scarcity of academic research is even more noteworthy in the case of small and medium enterprises (SMEs), especially considering that they operate with very limited resources to invest on technology, making it more difficult for SMEs to develop and expand their marketing and sales channels than for large and multinational companies (Scupola, 2009). Further, prior studies on MCEC focus on examining selected but limited variables of influence, but in general researchers lack a cohesive framework to systematically investigate the variables affecting the development of MCEC.

The main limitations of existing conceptual models include model complexity, lack of consistent criteria for variable selection and lack of cohesion. In addition, the constant evolution of marketing and sales channels -e.g. multi-channel, cross-channel and omnichannel operation- involve a constant revision of such frameworks, leading to a continuous addition, modification or deletion of the variables included in the theoretical models. Furthermore, there may be important differences in MCEC development across countries that can only be explained by region-specific factors.

Considering this state of affairs, the goal of this research is to develop a theoretical framework to help identify barriers and drivers of MCEC development, including region-specific factors. To achieve this goal, the study includes a literature review of extant research on the different variables affecting MCEC development and integrates them using a strategic view of the firm. As a result, we propose a concep- 
tual framework to study MCEC development and validate the proposal with a qualitative study conducted in two different countries.

The structure of this document is as follows. Section 2 summarizes the literature review and develops the proposal of the conceptual framework by applying a strategic view of the firm, including environmental scanning, competitive forces and organizational variables. After the introduction of the initial conceptual framework, Section 3 describes the research methodology and Section 4 details the data analysis and the results of the qualitative study. The main findings of the qualitative analysis are discussed in Section 5, which concludes with the final formulation of the conceptual framework. Finally, Section 6 presents the main contributions and limitations of the study.

\section{Development of the conceptual frame- work}

The elaboration of the conceptual framework consists of two steps. The first step seeks to identify relevant variables of influence in the development of MCEC, based on a literature review on the topic. Upon the identification of these variables, the second step aims to integrate them as part of a cohesive framework that presents the initial proposal, based on the application of external -environmental scanning and competitive forces- and internal -organizational- variables.

\subsection{Summary of the literature review}

The number of published studies that investigate variables influencing the development of MCEC is excessively large to be examined in this review. However, most of existing research focus on selected variables, without any clearly defined selection criteria and lacking an integrative view. Based on this, the literature review performed in this study only considers prior research that includes at least some kind of consistent classification or categorization of variables.

The selection of these studies, summarized in Table 1, further classifies the different variables as pertaining to the different categories: environmental, organizational, knowledge-related, technological, industry/sector-specific, or customer-related.

Table 1 Selected literature on varia-bles influencing the development of MCEC.

\begin{tabular}{|c|c|c|c|c|c|c|c|c|}
\hline Reference & Environmental & Organizational & Knowledge & Technological & Specific & Customer & Country & $\begin{array}{c}\text { Type and } \\
\text { sample size }\end{array}$ \\
\hline $\begin{array}{l}\text { Teo et al. } \\
\text { (1997) }\end{array}$ & $\begin{array}{l}\text { Competitive Intensity } \\
\text { Information Intensity } \\
\text { Government Support } \\
\end{array}$ & $\begin{array}{l}\text { Technology } \\
\text { Top Management Support } \\
\text { Management Risk Position }\end{array}$ & & $\begin{array}{l}\text { Compatibility } \\
\text { Relative Advantage }\end{array}$ & & & Singapore & $\begin{array}{c}\text { Quantitative } \\
\text { (188) }\end{array}$ \\
\hline $\begin{array}{l}\text { Golicic et al. } \\
(2002)\end{array}$ & $\begin{array}{l}\text { Speed } \\
\text { Connectivity } \\
\text { Information visibility } \\
\text { Market structures } \\
\text { Uncertainty } \\
\end{array}$ & & & & & & USA & $\begin{array}{l}\text { Qualitative } \\
\text { (22) }\end{array}$ \\
\hline $\begin{array}{l}\text { Fillis et al. } \\
\text { (2004) }\end{array}$ & $\begin{array}{l}\text { Globalization } \\
\text { Geographical and Physical } \\
\text { Barriers } \\
\text { Increased Competition } \\
\text { Government Policy }\end{array}$ & $\begin{array}{l}\text { Firm size } \\
\text { B2B/B2C } \\
\text { Market } \\
\text { Type of Product } \\
\end{array}$ & & & $\begin{array}{l}\text { Industry// } \\
\text { Sectorial } \\
\text { Factors }\end{array}$ & & UK & Theoretical \\
\hline $\begin{array}{l}\text { Wymer et al. } \\
(2005)\end{array}$ & $\begin{array}{l}\text { Competitive Pressure } \\
\text { Government } \\
\text { Market } \\
\text { Partners/Vendors } \\
\text { Supplier } \\
\end{array}$ & $\begin{array}{l}\text { Technical Expertise } \\
\text { Employee Reduction } \\
\text { Profitability } \\
\text { Capital }\end{array}$ & $\begin{array}{l}\text { Change Experience } \\
\text { Executive IT Experience } \\
\text { Innovativeness } \\
\text { Perceived need for change } \\
\text { Prior IT Experience } \\
\text { IT Trust }\end{array}$ & $\begin{array}{l}\text { Cost } \\
\text { IT Infrastructure } \\
\text { Reliability } \\
\text { Security } \\
\text { Technology Availability } \\
\end{array}$ & & & USA & $\begin{array}{l}\text { Quantitative } \\
\text { (102) }\end{array}$ \\
\hline $\begin{array}{l}\text { Pennanen et } \\
\text { al. (2006) }\end{array}$ & & & & & & $\begin{array}{l}\text { Competence } \\
\text { Integrity } \\
\text { Benevolence } \\
\end{array}$ & Finland & $\begin{array}{c}\text { Qualitative } \\
\text { (10) }\end{array}$ \\
\hline $\begin{array}{l}\text { AlGhamdi et } \\
\text { al. (2012) }\end{array}$ & $\begin{array}{l}\text { IT Infrastructure } \\
\text { Government Support } \\
\text { IT Learning Programs } \\
\text { Logistics Infrastructure }\end{array}$ & $\begin{array}{l}\text { Cost } \\
\text { Type of Product } \\
\text { Resistance to change }\end{array}$ & & $\begin{array}{l}\text { Technology Availability } \\
\text { Secure Online Payment }\end{array}$ & & Customer Online Trust & Saudi Arabia & $\begin{array}{l}\text { Quantitative } \\
\text { (148) }\end{array}$ \\
\hline $\begin{array}{l}\text { Yang et al. } \\
\text { (2014) }\end{array}$ & International Logistics & E-Marketing & & $\begin{array}{l}\text { International e-payment } \\
\text { E-commerce Service } \\
\text { Platform }\end{array}$ & & & China & $\begin{array}{l}\text { Quantitative } \\
\text { (313) }\end{array}$ \\
\hline $\begin{array}{l}\text { Kabango et } \\
\text { al. (2015) }\end{array}$ & Government & & & $\begin{array}{l}\text { Perceived Technological } \\
\text { Quality }\end{array}$ & & $\begin{array}{l}\text { Security, Fraud and Hacking } \\
\text { Awareness and Perceived } \\
\text { Usefulness } \\
\text { Accessibility } \\
\text { Perceived Functional Quality } \\
\text { Customer Online Trust }\end{array}$ & China & Theoretical \\
\hline $\begin{array}{l}\text { Ahmad et al. } \\
(2015)\end{array}$ & $\begin{array}{l}\text { External Change Agents } \\
\text { Pressures from Trading } \\
\text { Partners } \\
\text { Pressures from Competitors }\end{array}$ & $\begin{array}{l}\text { E-commerce Knowledge } \\
\text { Top Management Support }\end{array}$ & & $\begin{array}{l}\text { Perceived Relative } \\
\text { Advantage } \\
\text { Perceived Compatibility } \\
\text { Perceived Complexity }\end{array}$ & & & Malaysia & $\begin{array}{l}\text { Quantitative } \\
\text { (307) }\end{array}$ \\
\hline $\begin{array}{l}\text { Yaseen et al. } \\
(2016)\end{array}$ & $\begin{array}{l}\text { Government Support } \\
\text { Legislations } \\
\text { Logistics Infrastructure } \\
\text { Payment Systems } \\
\text { Awareness }\end{array}$ & & & & & & Jordan & $\begin{array}{l}\text { Qualitative } \\
\text { (12) }\end{array}$ \\
\hline
\end{tabular}




\subsection{A strategic view of MCEC development}

While Table 1 could be used as a basis for variable classification, it does not accurately reflect how companies, both large and SMEs, plan and execute their strategy. Instead, companies adopt a strategic view when considering the different aspects involving decisions related to the implementation of new technologies or the development of new sales channels. This view has been extensively validated in business contexts (Fahey \& Narayanan, 1986; Kotler \& Keller, 2006; Porter, 1985), facilitating a systematic and strategy-based approach to the study of the variables affecting MCEC development. It is also possible to establish a correspondence between the categories in Table 1 and the different components of strategic analysis. Thus, by adopting this view, the study differentiates three different groups of variables of influence, depending on where in the strategic analysis they are considered: environmental scanning -external analysis, general-, competitive forces - external analysis, specific- and organizational variables -internal analysis.

\subsubsection{Environmental scanning}

Environmental scanning covers the different external variables that may affect how the company operates, including policy, economic, social, technological, ecological and legal aspects, also known as PESTEL (Fahey \& Narayanan, 1986).

The decisions of governments, socio-demographic characteristics of the country and technology have a direct impact on business development. For instance, Public Administrations play a critical role when developing strategic technology plans for a country, but the effectiveness of the implementation is strongly linked to the incorporation of those technologies to business; an example of this is the strategic plan of Red.es in Spain, which sets the programmatic lines to be followed at an institutional level and assigns a budget to help companies wanting to accelerate their digitalization processes (Red.es, 2017), or ARSAT (2017) in Argentina, through the Federal Plan for Internet.

In the context of e-commerce, prior research focuses on the effect of applicable law (Fillis, Johannson, \& Wagner, 2004; Jensen, Kees, Burton, \& Turnipseed, 2003; Srinivasan, Lilien, \& Rangaswamy, 2002), urban infrastructure road, railroad and energy networks- and technical infrastructure -technology available and access to technology- (Aleid, Rogerson, \& Fairweather, 2009; Caldeira \& Ward, 2002; Miyazaki \& Fernandez, 2001; Yaseen, Alhusban, Dingley, \& Alhosban, 2016).

\subsubsection{Competitive forces}

Competitive forces include the different agents that directly affect a company's operation and its competition. Porter (1985) summarizes these agents in five forces: current and future competitors, suppliers, customers and substitutive products. However, the effect of Internet must be taken into account. Internet has changed the market rules, by lowering entry barriers for competitors and increasing product offering, and therefore fostering the development of e-commerce (Ahmad, Abu Bakar, Faziharudean, \& Mohamad Zaki, 2015; Haynes, Becherer, \& Helms, 1998; Pflughoeft, Ramamurthy, Soofi, Yasai-Ardekani, \& Zahedi, 2003).

Internet also causes a shift from vendors to customers, who have access to more information and alternatives (Haynes et al., 1998). Customers exert a pressure over businesses to adopt online channels to maintain, or not lose, their competitive advantages (Al-Qirim, 2004; Chen \& Williams, 1998), and also demand higher levels of quality service (Golicic, Davis, McCarthy, \& Mentzer, 2002; Nambisan \& Wang, 1999; Park \& Kim, 2003; Pennanen \& Paaki, 2006).

Companies may also establish commercial agreements with service providers to improve their activity. The provision of services in e-commerce comprises both logistics and technological infrastructure. Logistics services companies deliver the products sold in online shops to customers - external logistics-, while technology providers give support to platforms that enable online shopping (AlGhamdi, Nguyen, Nguyen, \& Drew, 2012; Yang, Yang, \& Yang, 2014). Companies may develop their own online shopping platforms, or use independent software platforms -e.g. Shopify, Magento- and marketplaces that make it possible to shop online and which have now become critical facilitators of e-commerce adoption (Urueña, Ballestero, \& Morais, 2016) -as an example, around 40 percent of European companies have used this type of platforms for product commercialization (Statista, 2017).

\subsubsection{Organizational variables}

Organizational variables refer to a company's internal elements that affect the development of MCEC at strategic and functional levels, covering strategic management, technology, internal logistics and customer relationship. Strategic management or strategic vision includes managerial support (Ahmad et al., 2015; Offstein \& Childers, 2008; Teo, Tan, \& Buk, 1997) and generation of competitive advantages (Alghaith, Sanzogni, \& Sandhu, 2010; Kuan \& Chau, 2001). 
Technology refers to employees' technical knowledge (Mehrtens, Cragg, \& Mills, 2001; Wymer \& Regan, 2005), innovation management complexity (Al-ghaith et al., 2010) and compatibility with the company's values and structure (Teo et al., 1997). Internal logistics covers efficient order management (Colla \& Lapoule, 2012), and customer relations consider the bidirectional flow of information between consumers and the company, which aims to better understand and address customers' needs (Golicic et al., 2002; Kabango \& Asa, 2015).

\subsubsection{Conceptual framework}

From the three different categories of variables presented above, Figure 1 offers a graphic representation of the conceptual framework used as a starting point for the analysis. The main goal of the qualitative analysis described in subsequent sections is to empirically validate this proposal.

Figure 1 Initial conceptual framework (in red squares, variables not included in prior studies)

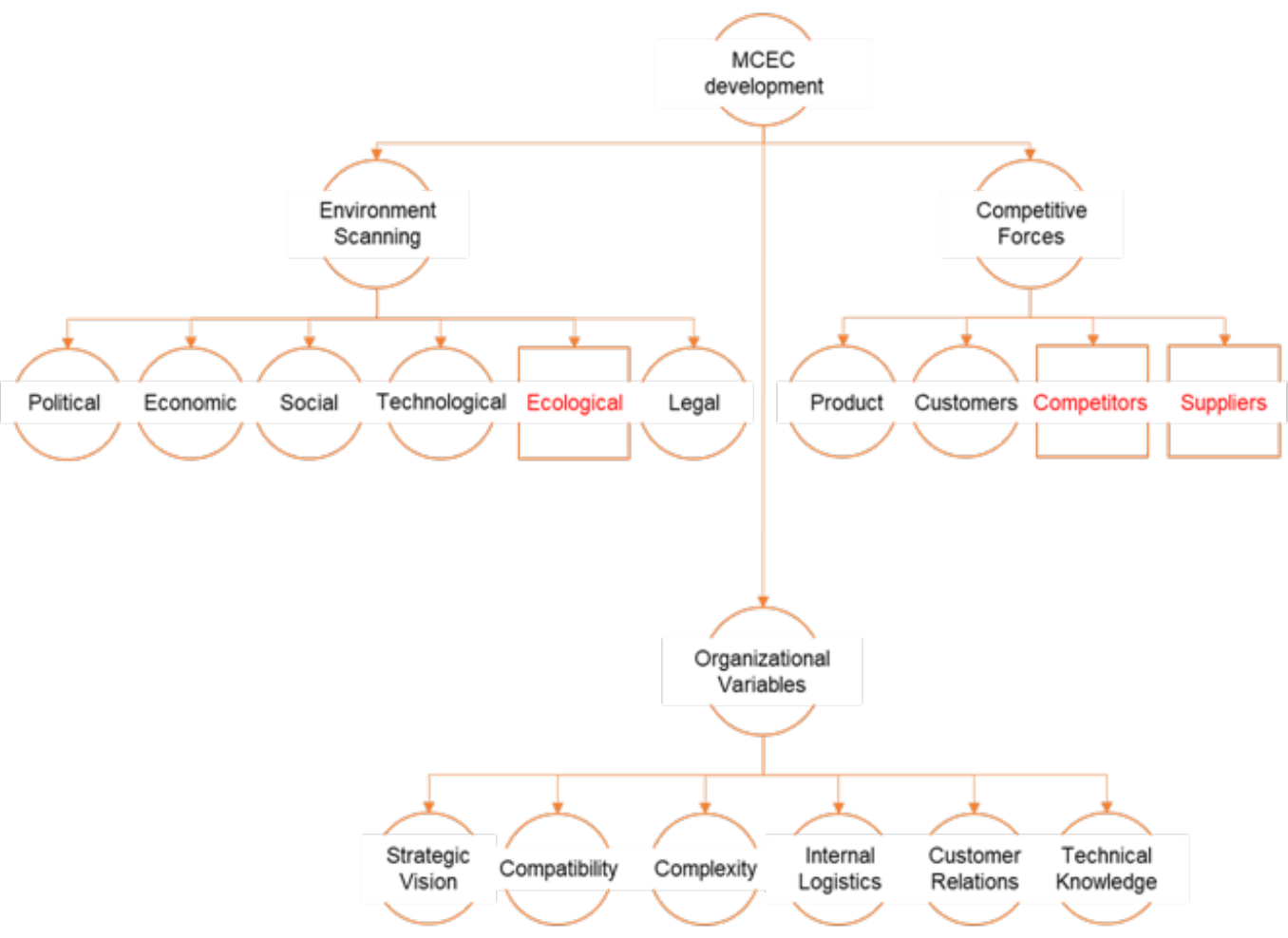

\section{Method}

Because of the exploratory nature of this research, the study proposes a qualitative study following the grounded theory method. The main advantage of qualitative analysis is that it allows researchers to discover concepts that are not reachable through statistical and quantitative methods (Strauss \& Corbin, 1998), such as the case of this study. While qualitative analysis as a research methodology has some disadvantages, mainly associated with subjectivity and generalizability of results (Cabrero \& Richard, 1996), its shortcomings do not limit in any way the internal -existence or not of a correspondence between construct and indicatoror external -correspondence between the findings and the empirical reality- validity of the analysis (Lincoln \& Guba, 1985).

\subsection{Sample of the study}

The sample of the study includes 10 Spanish and Argentinian companies from different sectors that sell their prod- ucts online, or online and using the physical channel -i.e. multi-channel operation. The interviewees include business owners, marketing directors and technology managers. Additionally, and to broaden the scope of the study, the analysis includes interviews to representatives of two of the main associations of e-commerce in each country -Adigital in Spain and CACE in Argentina- as well as representatives of marketplaces and logistics services providers. To preserve anonymity and confidentiality, the real names of the different companies have been ommited in this document.

\subsection{Data collection}

The grounded theory method facilitates the study of new situations by incorporating different interest groups. Even though interviews are considered the main data source, the method involves the collection of data from multiple sources, such as industry reports, news, websites, etc. (Corbin \& Strauss, 2015; Strauss \& Corbin, 1998). The study data were collected from semi-structured interviews to company man- 
agers. This type of interviews facilitates researchers to make script-based questions while allowing for a high degree of freedom that enables the emergence of original and new concepts formulated by the interviewee (Strauss \& Corbin, 1998).

The design of the initial script follows a similar approach to Wilson (1998) and was based on the topics emerged in the literature review (see Table 1), aligned with the research objectives, following an order that facilitates the flow of the interview without conditioning the responses of the interviewee. All the interviews were recorded to avoid any loss of information and ensure the accuracy of the analysis.

The interviews, which took place from July to December 2017, lasted between thirty and sixty minutes and covered general information about the company, the channels they used to sell their products, and the main challenges and benefits perceived about the incorporation of e-commerce to the company's activity. Two researchers conducted all the interviews. To reduce potential observation bias, two researchers other than the interviewers performed the transcripts and coding of the interviews, working independently. The additional benefits of this procedure are a reduction of the level of subjectivity and additional points of view that enrich the interpretation of the different answers (Offstein \& Childers, 2008). The total length of the 10 transcripts is about 150 pages long.

The coding process consists on the analysis and grouping of similar ideas by using unique or multiple dimensions (Miles \& Hubberman, 2014). The first stage includes an open coding scheme through the ideas emerging from the interviews. Then, and following the research model, a closed coding scheme served as a foundation for the redefinition and recoding of the ideas from the first stage (Glaser \& Strauss, 1967; Strauss \& Corbin, 1998). After definition of the coding scheme, it is necessary to build conceptual models that show the relations between the codes, which are the basis of model validation. To build such conceptual model, this research uses the software application Atlas.ti, which facilitates horizontal conceptualization; that is, linking the different elements freely, and not in a hierarchical way (Varguillas, 2006).

\section{Data analysis}

\subsection{Atlas.ti}

Atlas.ti facilitates the analysis of concepts mentioned in the interviews, as well as the elaboration of non-hierarchical relationship networks between the defined codes - each of which corresponds to a concept or study variable. The analysis included the elaboration of one network for each interview, two independent networks for each country and one global network.

After the elaboration of the networks, Atlas.ti analyzes characteristics of the text and generates values of groundedness or code frequency -i.e. how often a code has been applied or a concept has been mentioned-, which indicates the relevance of the concept, and density -or number of links between different pairs of codes. Fig. 2 shows an example of the analysis of one network.
Figure 2 Groundedness and density of codes in one of the networks of the study (concepts in Spanish)

\begin{tabular}{|c|c|c|c|c|c|}
\hline & Nombre & Enraizamien... & & Densidad & \\
\hline$\overline{0}$ & $>$ Proveedores & 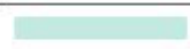 & & 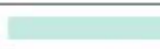 & 4 \\
\hline ० & $\nabla$ Características de la empresa & 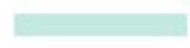 & 8 & 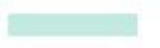 & 3 \\
\hline 0 & Comunicación & Ear & 3 & $\square$ & 1 \\
\hline o & Calidad percibida funcional & $\square$ & 3 & & 4 \\
\hline 0 & $\nabla$ Conocimiento tecnológico de la empresa & 四 & 2 & & 0 \\
\hline 0 & $\diamond$ Competencia & 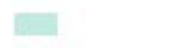 & 2 & $\square$ & 2 \\
\hline o & $\Delta$ Compatibilidad & $\square$ & 2 & 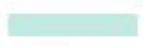 & 3 \\
\hline 0 & $>$ Logística interna & in & 1 & 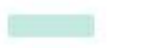 & 2 \\
\hline 0 & Seguridad, confianza, fraude y privacidad & 11 & 1 & 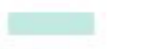 & 2 \\
\hline o & $\nabla$ Características del país & Eiv & 1 & $\square$ & 1 \\
\hline 0 & $\nabla$ Complejidad & [it & 1 & 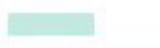 & 2 \\
\hline o & $\nabla$ Beneficio percibido por el cliente con EC & a & 1 & 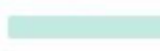 & 4 \\
\hline ० & $\diamond$ Características del cliente & E & 1 & 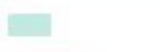 & 1 \\
\hline ० & $\nabla$ Consultores externos & & 0 & $\square$ & 2 \\
\hline
\end{tabular}


Based on that information, Atlas.ti facilitates the visualization of the networks, which were used in this study as a first step to validate the conceptual framework and make the comparison between both countries (Fig 3 and Fig 4).

Figure 3 Network of variables influencing MCEC development in Spain and relationships between variables (concepts in Spanish)

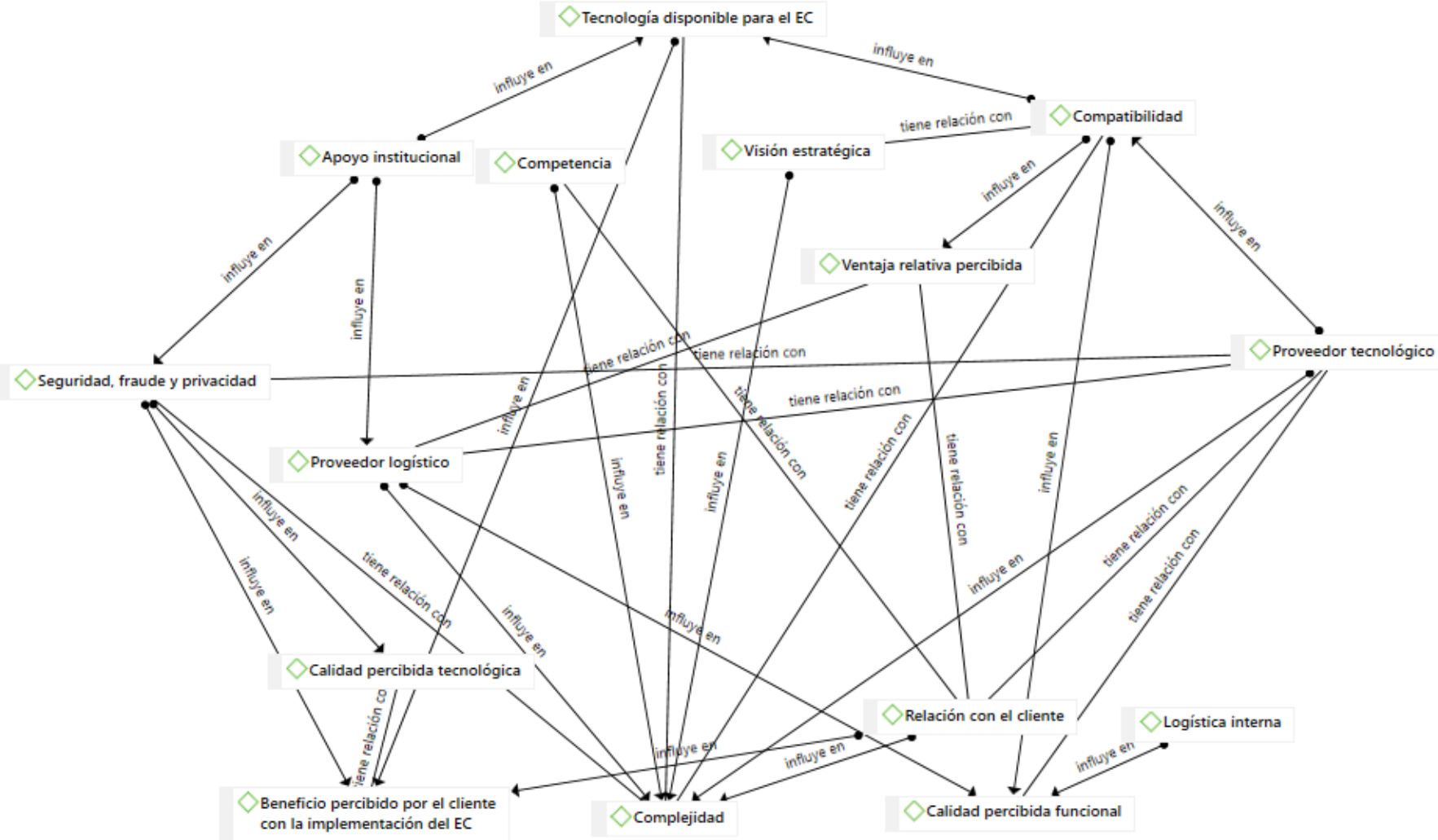

Figure 4 Network of variables influencing MCEC development in Argentina and relationships between variables (concepts in Spanish).

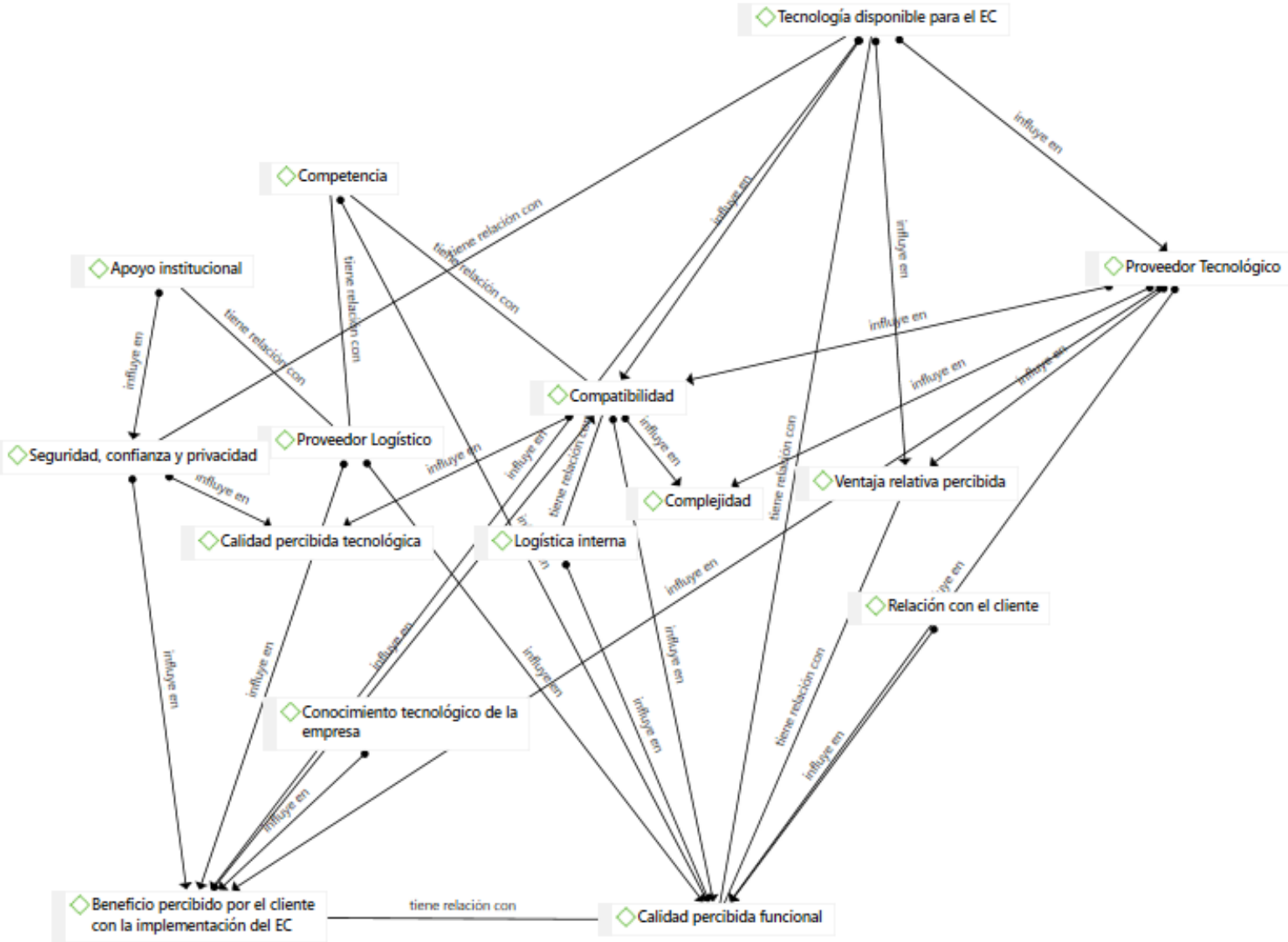


After the analysis of the relevance of the different variables of the conceptual framework and the relationships between them -in Atlas.ti-, the researchers went back to the original interviews to facilitate the explanation of the results. The following section summarizes the main findings of the detailed review of the interviews, focusing on the concepts that emerged in the analysis in Atlas.ti.

\subsection{Detailed analysis of the interviews}

\subsubsection{Environmental scanning}

Regarding environmental scanning, the results suggest that economic and ecologic aspects have no relevance in the development of MCEC, while legal, social -in terms of acceptance of e-commerce-, policy-related and technical aspects are highly relevant.

From the interviews, legal and policy-related aspects refer to fraudulent transactions, payment methods, data privacy and tax regulation, such as legal restrictions about who can process a credit card payment, high commission fees for credit card transactions or whether the origin of the funds is lawful. These aspects are especially relevant in Argentina, as the following statements show:

"At a given moment, there were legal restrictions concerning who could process a credit card payment (physically and non-physically), which have been constraining [us]" (Argentinian organization)

"Credit card commissions were very high. When they lower them down by legal requirement, commercial barriers also decrease" (Argentinian organization)

"Regulatory issues that are very necessary, even though they may complicate business operations, are related to the lawfulness of transactions, the lawfulness of the fund sources" (Argentinian organization)

In Spain, companies mention tax regulation as a barrier, primarily when considering shipping to special tax zones, such as the Canary Islands:

"When you sold and delivered a product to the Canary Islands, and the order was over 20 euro, the customer had to pay custom taxes. Now they have raised it to 150 euro" (Spanish organization)

Technical aspects are mostly focused on the availability of technology and security, the latter being primarily associated with cybersecurity-related issues.

"I think that allowing to pay with mobile devices using, for example, Apple ID, and that customers do not have to provide their credit card details, would help in this matter" (Argentinian organization)

"We find this more often than we would like to. Usually this type of things is detected. I would say that there are three ways [to detect them]. The main one is that the person is aware that he has unauthorized charges. On the other hand, when the authorities get in touch with us because they have received a report for fraudulent use of cards. Third, we work with payment platforms that allow us to integrate certain mechanisms to detect this type of fraud"(Spanish organization)

Finally, the fact that most of the society is starting to see e-commerce as a secure and trusted method to shop causes an increase in the demand for online commerce:

"Let us say that the inner part of Argentina is living an 'Internet childhood' and only Buenos Aires is going through 'adolescence,', (Argentinian organization)

"We are seeing since some years now that the market is consolidating, growing at double digits, although dissimilarly across the different sectors. This is evidently still far from the United Kingdom or the United States, who are the big leaders" (Spanish organization)

\subsubsection{Competitive forces}

Concerning competitive forces, only customers and providers stand out as the main influencing variables. The relevance of the other two variables is relative. For example, the importance of competitors is not associated with e-commerce, but rather to the commercial sphere in general. Regarding product, the interviewees concur that its effect heavily depends on the type of product, and therefore its analysis would require a more detailed analysis.

Companies emphasize the benefit -in both countriesand increase in quality service -in Spain- from introducing MCEC:

"I think that, above all, there are two issues. People who do not have any physical store close to their house and who can, with Internet, now shop. Also, customers who use the web to look up products without having to travel to the store unnecessarily" (Argentinian organization; benefit)

"Many people go into online shopping due to the idea that prices are lower" (Spanish organization; benefit)

"The decision of many companies is to guarantee a minimum [level of] quality both in presales and post-purchase. I mean, that the user receives a correct advice and that the customer receives the product he has actually purchased" (Spanish organization; quality) 
"We try to have the customer identified, and it there is any problem, he is phoned. We have a very close treatment with customers" (Spanish organization; quality)

Business also stress the capital role of logistics services providers, more so than that of technology providers. While the perception is that technology providers are necessary partners, there is a general concern about the provision of logistics services, higher in the case of Argentina, because they have a stronger impact in quality of service -i.e. shipping costs and delivery dates.

"Logistics is other challenge because it is required to have mature processes when providing these services, and you do not always find it [a provider]" (Argentinian organization)

"The matter of logistics is another big challenge, not only regarding dates but also costs. For example, because of the type of product we sell-electronic appliances-, sending something to another city may mean transportation costs of 30 percent of the value of the product. We prefer not to sell the product under those conditions. It is true that it depends on the type of product (size, weight, shipping address, etc.)" (Spanish organization)

"We are a small company, they do not provide us these services with the required quality and speed that they give to larger companies" (Spanish organization)

"Deliveries (logistics) are another constant challenge. We are living a global revolution. The need for immediacy in online orders. Our type of product fits very well with 24-hour delivery, addressing our customers' needs" (Spanish organization)

In the case of marketplaces, while they may be considered as competitors, there is a consensus that they are needed to further develop MCEC in the country, as they reduce the risk associated to lack of knowledge of the brand while also serving as additional sales channel.

\subsubsection{Organizational variables}

The analysis reveals two influencing, and closely related, organizational variables -complexity and compatibility-, which are associated with the implementation of the technology and its fit with the structure of the company. Incorporating digital channels demands adaptation of the existing information systems to fulfill the technical requirements of online shopping -e.g. stock management, delivery and return processes:

"Currently, we only have a particular software problem that we must solve as a company [as a whole], and not just at the e-commerce level. We are selling online and delivering at branch offices, but we are not integrating the stock levels" (Argentinian organization)
"The problem that we are having is that we need a tool to channel all operations, because if not, it generates trouble for the workers managing it. Cultural and social change is making it possible that customers reach you by any channel" (Argentinian organization)

"We are trying to develop a sales assistant that allows, from any physical store, well, to see if there is stock, in which store it is [located], to reserve [the product], see if we also have customer data, by preferences, by sections... " (Spanish organization)

In both countries, managers also mention managerial support, which is related to strategic vision. Managerial support stands out as a more relevant variable in the case of Argentina, probably due to the differences in the degree of MCEC development in each region.

"There was an initial organizational issue. While the older managers did not see it clear, they did not 'put a stick on the wheel' either. It took a lot to have them seriously consider the online channel, for example when offering the product did not have the same 'weight' as the physical branch office. That has changed now" (Argentinian organization)

"Currently there are a lot of black-market offline sales. In contrast, most of online sales should be legal because around 90 percent of operations use credit card or payment gateways. The cultural matter is again one of the essential issues" (Argentinian organization)

\section{Discussion of results and formulation of the final conceptual framework}

The findings from the qualitative analysis provide additional information to refine the initial model shown in Fig. 1. The different modifications to the initial proposal may be grouped into three different categories: confirmed barriers and drivers of MCEC development -including further refined variables-, variables of relative relevance depending on country-specific characteristics and irrelevant variables -the latter are excluded from the framework.

The study reveals that policy, legal and technological aspects of environmental scanning are key barriers to MCEC development. In general, companies and organizations perceive that current regulations and policies, at regional and countrywide levels, are preventing them from successfully developing their MCEC strategies. More specifically, they are especially concerned about differences in taxes or commission fees, and they think that only through policy-making it will be possible to overcome them. Interestingly, while the existence or not of physical infrastructure does not seem to be a critical issue, technological aspects seem to impede the development of MCEC. From the analysis, technological elements of environmental scanning have been divided into aspects related to the availability of technology and se- 
curity. Regarding the former, the absence of specific public initiatives or investment from the private sector may be an obstacle for companies with limited resources or located in remote areas to implement MCEC strategies; as for the latter, companies are still very concerned about fraud.

The study shows that there are still organizational barriers to MCEC development. Companies do not seem to consider aspects related to internal logistics important for the development of MCEC, most likely because they do not think that there is need for much adaptation to implement multi-channel e-commerce strategies -it is not clear whether the same would apply to new companies. However, they are aware of the need to adequately manage all data associated with those processes. Adapting existing practices and processes to multi-channel e-commerce operations involves the implementation of new systems to adequately integrate the different channels because customers want a seamless shopping experience, which in turn demands managing a larger volume of information. Therefore, companies are afraid of having to incorporate complex systems, or that the new systems are not compatible with current business operation and processes.

This finding points out to a big opportunity for software companies able to provide this kind of services at competitive prices and help overcome this barrier. That opportunity is perceived by the interviewees as one of the main drivers of MCEC development, because technology suppliers are no longer seen just as a cost or unnecessary, but rather as essential partners.

Companies and organizations also stress the critical role of logistics services providers as a potential barrier; in this case, there are two additional considerations: first, that customers' perception of the overall quality of service of may largely depend on an adequate provision of logistics services due to their impact on delivery dates and total cost; interestingly, the study found no differences between both countries, which have significantly different sizes and 'capital versus rest-of-the-country' configurations -centric-based in the case of Spain and periphery or remote-based in the case of Argentina.

The study identifies additional drivers of MCEC development. First, at a macro level, the society in general seems to be more than ready for online commerce, probably led by the incorporation of a large cohort of digital natives and millennials to the consumer market. Further, the companies perceive that consumers have lost their distrust in online payments. This perception contrasts with the results conducted in the past decade, which identified consumers' lack of trust in e-commerce as one of the main barriers to online commerce adoption.

Second, related to the first, companies feel that consumers have a clear perception of the benefits derived from the use of MCEC, and that is a compelling reason for them to expand their operation to the online space. Further, it is worth noting that companies seem to share the idea that they need to address consumers' needs in two different steps, focusing on providing and adequate but effective and useful service in countries in earlier stages of development-Argentina-, and then adding a focus on quality and customer experience on top of that -Spain-, to provide customers with a strong value proposal and establish long-lasting and successful customer relationships.

There are also some differences in the relevance of strategic vision between both countries, with Argentinian companies emphasizing the need for managerial support to foster development of MCEC, and therefore the role of managerial support seems to be contingent on the level of development of each country.

Finally, the study finds that aspects related to economy and ecology at a macro level -environmental setting-, product and competitors -competitive forces- and internal logistics, and technical knowledge -organization- do not seem to be relevant for the development of MCEC -i.e. they do not act like barriers or drivers. From the interviews, the study cannot completely discard their influence on business operations, but at a level different than affecting development of MCEC. For instance, the status of national economy has a direct impact on financing or consumer purchasing power, but that occurs irrespective of whether the company transitions or not to MCEC. Something similar happens with competitors and products: the former are considered to operate at a sector or industry level, and companies have accepted that competition is now global; the latter would only have potential impact regarding problems associated with external logistics, due to the characteristics of the product, such as size, materials, etc. Finally, the incorporation of technology suppliers as partners reduces the need for additional technical knowledge, allowing companies to focus on their core activities.

From the above, Fig. 5 summarizes the final conceptual framework for the study of MCEC development. Fig. 5 follows a color pattern that identifies green variables (circles) as drivers, red variables (squares) as barriers, yellow variables (triangles) as potential barriers or drivers contingent on the country and grey-faded variables as non-relevant. 
Figure 5 Final conceptual framework for the study of MCEC

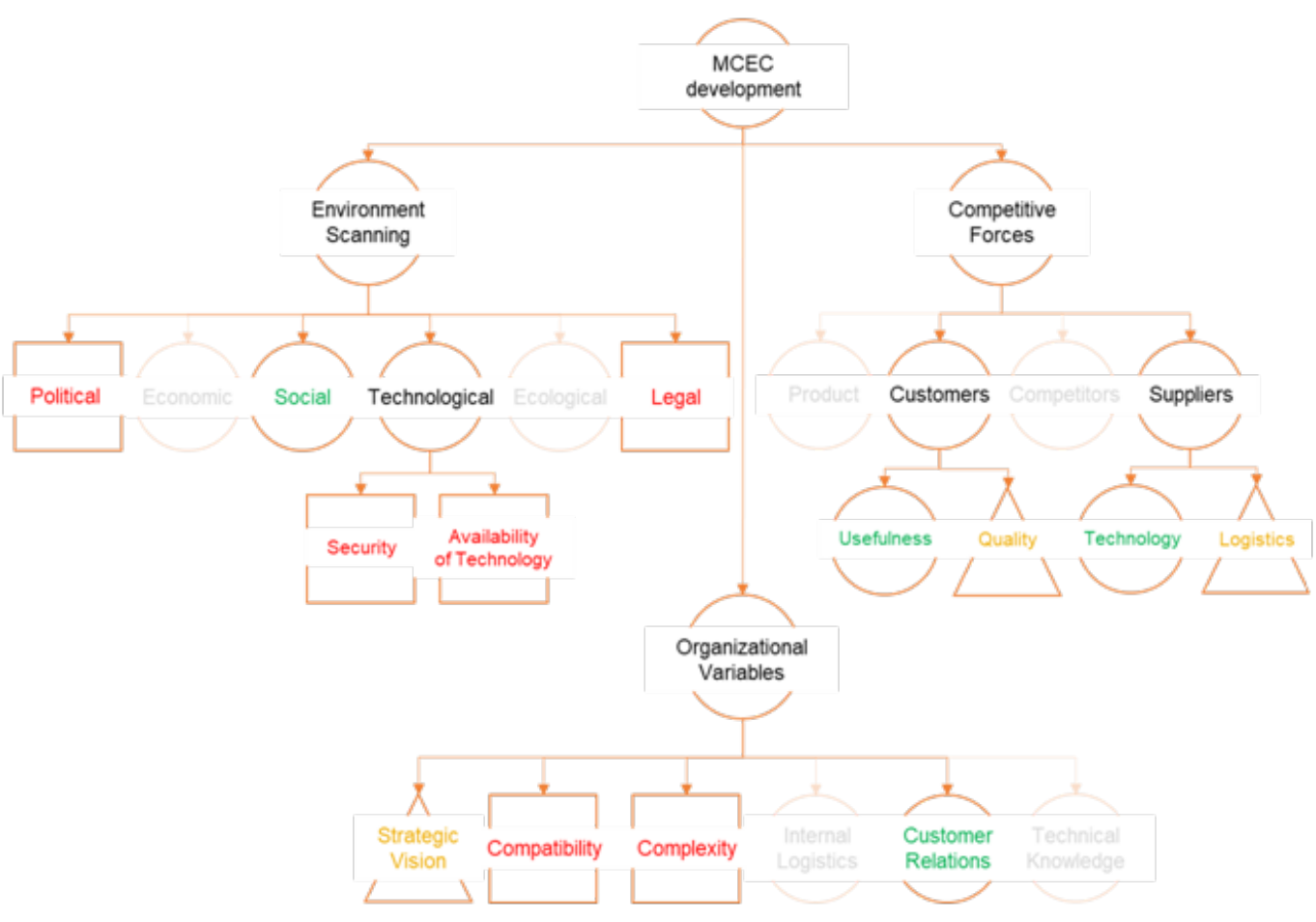

6.2. Implications for practice

\section{Contributions of the study}

The study investigates barriers and drivers of MCEC development across different countries. The exploratory nature of the research offers valuable insight for researchers, institutions, governments and companies.

\subsection{Implications for theory}

From an academic perspective, the study proposes a cohesive, holistic and theory-grounded framework that incorporates a strategic view of the firm, in line with how companies plan and implement their multi-channel strategies. The framework is built upon existing theory and establishes three different groups of variables that cover external -environmental scanning, competitive forces- and internal -organizational variables- views of the market and the organization. The study further identifies which variables are currently perceived as barriers or drivers of MCEC development, as well as those that might be dependent on country-specific characteristics and those not deemed relevant.

The study adds a new variable to the model: customer relationships. While the consideration of customer relations is not new to research on multi-channel e-commerce, the approach used in this study is a novelty, as the interviews confirm. Companies and organizations perceive a shift on how they should conduct their business in the new digital landscape and are aware that current systems and technologies facilitate strengthening the link between customer and company, significantly improving personalization, quality of service and customer experience.
For institutions and policy-makers, the final framework highlights the importance of the legal and regulatory aspects as barriers and drivers of MCEC. From the offer side, further regulation of payment systems, clear, unified and competitive taxation rates, and measures oriented to combat fraud would be highly beneficial to give impulse to MCEC. From the demand side, it is still necessary to keep working on communicating the benefits associated to e-commerce and providing information oriented to increase the perception of trust and security among consumers. Besides, as confirmed by several prior studies -e.g. Teo et al., 1997; Wymer et al., 2005; Yaseen et al., 2016-, further actions aiming at enhancing transportation and technology infrastructures would contribute to improve the development of online activities and their integration with existing practices.

The study also points out the external and internal elements that should be taken into account by companies willing to incorporate multi-channel electronic commerce to their business operations. The findings suggest that a careful global planning, and not purely operational, of digital strategy and channel integration minimizes problems derived from the complexity of information management systems and compatibility issues. Additionally, such a plan allows companies to identify potential technological and workforce limitations and constraints, and facilitates overcoming these barriers through the association with technology and logistics services suppliers to lower risks. 


\subsection{Differences between countries}

The analysis shows differences between both countries regarding the relative influence of the different variables on MCEC development. One finding worth exploring is the idea that the level of quality of service demanded by consumers may be associated with the level of MCEC development in the country. For example, the main concern for Argentinian companies and organizations is related with the adequate provision of the service -e.g. that the product arrives in a good state-, whereas quality of service -shipping dates, order tracking, etc.- is not currently an urgent issue. This contrasts with the Spanish context, where customers demand variety of shipping methods -e.g. shipment to an address, pick-up in store, convenience points, etc.- availability of products and shorter delivery windows.

As the analysis shows, the study cannot discard the impact of geographical characteristics of the country, which may hamper the effectiveness of logistics services, leading to the perception of a lower quality of service -it is worth noting that Argentina is five times larger than Spain and that its level of infrastructure development is significantly lower (INDEC, 2017; INE, 2017).

Finally, the study also finds differences in the availability and acceptance of different payment systems and methods: even though the state and Argentinian banks are undergoing a process of stimulation of electronic payment methods (BCRA, 2017), the acceptance of such payment methods in Argentina is still far below the Spanish adoption rates.

\subsection{Limitations and future research}

The study is not exempt from limitations. First, the qualitative and exploratory nature of the research might limit the generalizability of results to other contexts. Therefore, the extension of the study to other countries with different cultures and levels of MCEC development would be very helpful to confirm the findings of this research. In the same line, while the characteristics and size of the sample in this study are similar to those used in previous studies, increasing the number of interviewees and including representatives of recently created companies would add richness and depth to the analysis. Furthermore, the study groups companies from different sectors; future research should confirm whether some of the findings of this study are sector-specific.

Lastly, the study only adopts a company view, and as such the analysis did not include a consumer perspective. Incorporating both elements of the market -supply and demandin the analysis is a necessary step toward a complete understanding of the actual barriers and drivers of MCEC, and how to effectively foster its development. Only a balance between companies' and consumers' needs, pains, concerns and attitudes may help overcome the obstacles on both sides and deploy actionable plans that leverage the different drivers of MCEC.

\section{Acknowledgment}

This research has been supported by the "Programa de Becas Iberoamérica. Santander Investigación. Santander Universidades. Curso académico 2017-2018” program.

\section{References}

Ahmad, S. Z., Abu Bakar, A. R., Faziharudean, T. M., \& Mohamad Zaki, K. A. (2015). An Empirical Study of Factors Affecting e-Commerce Adoption among SMEs in a Developing Country: Evidence from Malaysia. Information Technology for Development, 21(4), 555-572.

Al-ghaith, W., Sanzogni, L., \& Sandhu, K. (2010). Factors Influencing the Adoption and Usage of Online Services in Saudi Arabia. EJISDC, 40(1), 1-32.

Al-Qirim, N. A. Y. (2004). A framework for e-commerce research in SMEs. Electronic Commerce in SMEs: Frameworks, Issue and Implications, 1-16.

Aleid, F., Rogerson, S., \& Fairweather, B. (2009). Factors Affecting Consumers Adoption of Ecommerce in Saudi Arabia from a Consumers' Perspective. IADIS International Conference E-Commerce, (March 2008), 11-18.

ARSAT. (2017). Plan Federal de Internet. Retrieved from http://bit.ly/2naIDj6

BCRA. (2017). Medios de Pago Electrónicos. Retrieved from http://www.bcra.gob.ar/SistemasFinancierosYdePagos/Medios_de_pago_electronicos.asp

Cabrero, J., \& Richard, M. (1996). El debate investigación cualitativa frente a investigación cuantitativa. Enfermería Clínica, 6(5), 212-217.

Caldeira, M. M., \& Ward, J. M. (2002). Understanding the successful adoption and use of IS/IT in SMEs: an explanation from Portuguese manufacturing industries. Info Systems Journal, 12, 121-152.

Chen, J.-C., \& Williams, B. C. (1998). The Impact of Electronic Data Interchange (EDI) on SMEs: Summary of Eight British Case Studies. Journal of Small Business Management, 36(4), 68-72. https://doi.org/Article

Corbin, J., \& Strauss, A. (2015). Basics of Qualitative Research: Techniques and Procedures for Developing Grounded Theory (4th Editio). Sage Publications. 
Fahey, L., \& Narayanan, V. (1986). Macroenvironmental analysis for strategic management. St.Paul, Minnesota: South-Western.

Fillis, I., Johannson, U., \& Wagner, B. (2004). Factors impacting on $\mathrm{e} \square$ business adoption and development in the smaller firm. International Journal of Entrepreneurial Behavior \& Research, 10(3), 178-191.

Frasquet, M., Mollá, A., \& Ruiz, E. (2015). Identifying patterns in channel usage across the search, purchase and post-sales stages of shopping. Electronic Commerce Research and Applications, 14(6), 654-665.

Glaser, B. G., \& Strauss, A. L. (1967). The Discovery of Grounded Theory: Strategies for Qualitative Research. Chicago: Aldine.

Golicic, S. L., Davis, D. F., McCarthy, T. M., \& Mentzer, J. T. (2002). The impact of $\mathrm{e} \square$ commerce on supply chain relationships. International Journal of Physical Distribution \& Logistics Management, 32(10), 851-871.

Haynes, P. J., Becherer, R. C., \& Helms, M. M. (1998). Small and mid-sized businesses and Internet use: Unrealized potential? Internet Research, 8(3), 229-235.

Jensen, T., Kees, J., Burton, S., \& Turnipseed, F. L. (2003). Advertised reference prices in an internet environment: effects on consumer price perceptions and channel search intentions. Journal of Interactive Marketing, 17(2), 20-33. https://doi.org/10.1002/dir.10052

Kabango, C. M., \& Asa, A. R. (2015). Factors influencing e-commerce development: implications for the developing countries. International Journal of Innovation and Economic Development, 1(1), 64-72.

Kotler, P., \& Keller, K. L. (2006). Marketing Management (12th Ed.). Pearson Education, Inc.

Kuan, K., \& Chau, P. (2001). A perception-based model for EDI adoption in small businesses using a Technology Organization Environment framework. Information \& Management, 38(8), 507-521.

Lincoln, Y. S., \& Guba, E. (1985). Naturalistic inquiry. (E. CA Sage, Ed.).

Mehrtens, J., Cragg, P. B., \& Mills, A. M. (2001). A model of Internet adoption by SMEs. Information and Management, 39(3), 165-176.

Miyazaki, A. D., \& Fernandez, A. (2001). Consumer Perceptions of Privacy and Security Risks for Online Shopping. The Journal of Consumer Affairs, 35(1), 27-44.
Nambisan, S., \& Wang, Y.-M. (1999). Roadblocks to Web Technology Adoption? Communications of the ACM, 42(1), 98-101.

Offstein, E. H., \& Childers, J. S. (2008). Small business e-commerce adoption through a qualitative lens: theory and observations. Journal of Small Business Strategy, 19(1), 32-50.

Park, C., \& Kim, Y. (2003). Identifying key factors affecting consumer purchase behavior in an online shopping context. International Journal of Retail \& Distribution Management, 31(1), 16-29. https://doi. org/10.1108/09590550310457818

Pennanen, K., \& Paaki, M. K. (2006). A Qualitative Analysis of Consumers' Perceptions of the Trustworthiness of $\mathrm{e}^{-}$ Commerce. Frontiers of E-Business Research.

Pflughoeft, K. A., Ramamurthy, K., Soofi, E. S., Yasai-Ardekani, M., \& Zahedi, F. (2003). Multiple Conceptualizations of Small Business Web Use and Benefit. Decision Sciences, 34(3), 467-512.

Porter, M. E. (1985). Competitive Advantage: Creating and Sustaining Superior Performance. NY: FreePress.

Ranganathan, C., \& Ganapathy, S. (2002). Key dimensions of business to consumer web sites. Information \& Management, 39(6), 457-465.

Schröder, H., \& Zaharia, S. (2008). Linking multi-channel customer behavior with shopping motives: An empirical investigation of a German retailer. Journal of Retailing and Consumer Services, 15(6), 452-468. https://doi. org/10.1016/j.jretconser.2008.01.001

Scupola, A. (2009). SMEs' e-commerce adoption: Perspectives from Denmark and Australia. Journal of Enterprise Information Management, 22(1-2), 152-166. https:// doi.org/10.1108/17410390910932803

Srinivasan, R., Lilien, G. L., \& Rangaswamy, A. (2002). Technological Opportunism and Radical Technology Adoption: An Application to E-Business. Journal of Marketing, 66(3), 47-60.

Strauss, A., \& Corbin, J. (1998). Basics of qualitative research. Techniques and procedures for developing grounded theory (2nd ed.). Sage Publications, Inc.

Teo, T. S. H., Tan, M., \& Buk, W. K. (1997). A Contingency Model of Internet Adoption in Singapore. International Journal of Electronic Commerce, 2(2), 95-118. 
Wymer, S. A., \& Regan, E. A. (2005). Factors Influencing e-commerce Adoption and Use by Small and Medium Businesses. Electronic Markets, 15(4), 438-453.
Yaseen, H., Alhusban, M., Dingley, K., \& Alhosban, A. (2016). Facilitating E-Commerce in Jordan: A Qualitative Analysis. International Journal of Digital Society, 7(4), 1206-1213. 